\title{
The Efficiency of the Er: YAG Laser and Photon- Induced Photoacoustic Streaming (PIPS) as an Activation Method in Endodontic Irrigation: A Literature Review
}

\author{
Quy Linh Do ${ }^{1}$, Alexis Gaudin ${ }^{1,2,3^{*}}$ \\ ${ }^{1}$ Clinical Investigation Unit 11 Odontology, CHU Nantes, Nantes, France \\ ${ }^{2}$ Department of Endodontics and Restorative Dentistry, Faculty of Dental Surgery, University of Nantes, Nantes, France \\ ${ }^{3}$ Inserm, UMR 1229, RMeS, Regenerative Medicine and skeleton, University of Nantes, ONIRIS, Nantes, France
}

\author{
*Correspondence to \\ Alexis Gaudin, Department \\ of Endodontics, University of \\ Nantes, 1 place Alexis Ricordeau, \\ Nantes, 44093 Nantes Cedex 01, \\ France Phone: +33 (0)6 4967 \\ 7083 ; \\ Email: \\ alexis.gaudin@univ-nantes.fr
}

Published online June 21, 2020

\begin{abstract}
In the field of endodontics, lasers have been used for a long time for the optimization of Endodontic irrigation in particular. The laser-activated irrigation ( $\mathrm{LAI}$ ) technique is based on the photomechanical effects of the lasers at low settings. They create specific cavitation phenomena and acoustic streaming in intracanal fluids. More recently, a new technique with a Er:YAG laser has been used with sub-ablative energy $(20 \mathrm{~mJ}, 15 \mathrm{~Hz})$ and ultra-short pulses $(50 \mu \mathrm{s})$. This leads to intracanal cavitation and shockwaves as a result of photoacoustic and photomechanical effects. This phenomenon is called photon-induced photoacoustic streaming (PIPS). PIPS and Laser activated irrigation are described in the literature as a revolutionary and powerful method to activate the irrigant; however, systematic literature on this topic is missing. This review compares the literature on Er:YAG LAI and PIPS on endodontic irrigation with other irrigation methods. An article search was performed on the PubMed database using a series of keywords related to endodontic irrigation, including Er:YAG LAI and PIPS; 59 articles were selected for the review according to the inclusion and exclusion criteria. No in vivo study was found. The Er:YAG LAI and PIPS outperformed other methods in 33 of the 59 articles. There was a great variety in the study designs including bacterial incubation time, laser parameters, irrigation protocols, and irrigating solution used. The evidence suggests that the Er:YAG LAI and PIPS are promising in canal disinfection as well as debris and smear layer removal. However, the large variety in the study methods makes the results less significant. Further studies are needed to better evaluate the efficiency of these techniques, especially in vivo studies.

Keywords: Endodontic irrigation; Er:YAG laser; Laser activated irrigation; Photon-induced photoacoustic streaming.
\end{abstract}

\section{Introduction}

Endodontics preserves pathologic teeth and restores their functions. A successful endodontic treatment should accomplish the triad of endodontics: shaping, cleaning, and filling of the root canal systems in three dimensions. Although a combination of those three factors needs to be achieved, it is widely accepted that root canal disinfection is central to the outcome of root canal treatment. ${ }^{1,2}$ This procedure involves removing pulp tissue, bacteria, and related irritants from the root canal systems as well as the smear layer produced during the shaping step. ${ }^{3}$

Many irrigants, devices, and methods have been introduced for efficient disinfection. Sodium hypochlorite $(\mathrm{NaOCl})$ is considered the gold standard for root canal irrigation thanks to its wide-spectrum, nonspecific antimicrobial efficacy, and great tissue-dissolving capacity. ${ }^{4} \mathrm{NaOCl}$ remains the best primary irrigant versus other traditional antimicrobial agents such as hydrogen peroxide, iodine, and chlorhexidine (CHX) as well as novel agents like MTAD (a mixture of doxycycline, citric acid, and detergent) and QMix (a mixture of ethylenediaminetetraacetic acid (EDTA), CHX, and detergent). ${ }^{5}$

While powerful as an efficient irrigant, $\mathrm{NaOCl}$ cannot accomplish another important aim of root canal irrigation-dissolving inorganic debris and removing and preventing the formation of the smear layer on the root canal walls during instrumentation. ${ }^{6}$ In addition, root canal calcifications restricting mechanical preparation are common. Therefore, the use of chelator solutions

Please cite this article as follows: Do QL, Gaudin A. The Efficiency of the Er:YAG laser and photon-induced photoacoustic streaming (PIPS) as an activation method in endodontic irrigation: A literature review. J Lasers Med Sci. 2020;11(3):316-331. doi:10.34172/jlms.2020.53. 
such as EDTA $^{7}$ and citric acid ${ }^{8,9}$ at the end of mechanical instrumentation is recommended. The demineralizing agents allow the removal of the smear layer, which consists of dentine debris, pulpal residues, bacteria, and endotoxins. This offers better cleaning and achieves a closer interface between obturation materials and root canal walls. ${ }^{10,11}$ While the antiseptic effect of chelators is very limited, an alternating irrigating protocol of $\mathrm{NaOCl}$ and EDTA may be more efficient than $\mathrm{NaOCl}$ alone. ${ }^{12}$ A final rinse with a disinfecting solution after the smear layer removal is often required because EDTA and citric acid can reduce the antimicrobial properties of $\mathrm{NaOCl} .^{13,14}$

Classically, the irrigation solutions are dispensed from a handheld syringe utilizing a gauge needle with various vent designs. However, this conventional method has several disadvantages due to the complexity of the root canal system and the limitations of the syringe/needle irrigation technique. ${ }^{15}$ Many disinfection methods have been developed to presumably acquire better intracanal cleaning. Different irrigant agitation techniques have been introduced, including pumping a gutta percha master cone in a fluid-filled canal, activating irrigants with ultrasonic metal tips or sonic nonmetal tips, and energizing irrigants with lasers.

Several laser wavelengths have been investigated for root canal cleaning and disinfecting: erbium:yttrium aluminum garnet (Er:YAG), $2940 \mathrm{~nm}$; erbium, chromium:yttrium scandium gallium garnet (Er,Cr:YSGG), $2780 \mathrm{~nm}$; neodymium:yttrium aluminium garnet (Nd:YAG), 1064 $\mathrm{nm}$; diode, 635 to $980 \mathrm{~nm}$; potassium titanyl phosphate (KTP), $532 \mathrm{~nm}$; carbon dioxide $\left(\mathrm{CO}_{2}\right), 9600$ and $10600 \mathrm{~nm}$. The wavelengths of erbium lasers (Er:YAG, Er,Cr:YSGG) are well absorbed in water and hydroxyapatite; thus, they may have value in agitating irrigation solutions. ${ }^{16}$

The laser-activated irrigation (LAI) technique is based on the creation of cavitation phenomena and acoustic streaming in intracanal fluids related to the photomechanical effects of the lasers at low settings. ${ }^{17}$ The strong absorption of the Erbium laser energy in water and $\mathrm{NaOCl}$ causes vaporization and formation of vapour bubbles. These large elliptical bubbles implode after 100 to $200 \mu \mathrm{s}$, inducing the secondary cavitation effect. More recently, a new technique with a Er:YAG laser has been used with sub-ablative energy $(20 \mathrm{~mJ}, 15 \mathrm{~Hz})$ and ultra-short pulses $(50 \mu \mathrm{s})$. This leads to intracanal cavitation and shockwaves as a result of photoacoustic and photomechanical effects. ${ }^{18}$ This phenomenon is called photon-induced photoacoustic streaming (PIPS). In contrast to LAI in which the tips are positioned 5 $\mathrm{mm}$ from the apex, PIPS specific tips are kept at the entrance of the root canal, reducing the need for large file instrumentation. ${ }^{19,20}$ The aim of this study was to review previously published studies and evaluate the effectiveness of Er:YAG LAI with PIPS versus other currently used methods and techniques in endodontic irrigation.

\section{Literature Search Methodology}

Data Sources and the Search Strategy

The review was performed as determined by the Preferred Reporting Items for Systematic Review and Meta-Analyses (PRISMA) protocols. ${ }^{21}$ The structured research question was developed by using the population, intervention, comparison, and outcome (PICO) framework: Do PIPS and Er:YAG LAI: (I) perform better (O) than other irrigation methods $(\mathrm{C})$ in in vitro experiments based on extracted tooth samples $(\mathrm{P})$ ? A comprehensive literature search was conducted on PubMed (MEDLINE), Ovid (MEDLINE), Web of Science (all databases), SCOPUS, and the Cochrane library from 2008 to 2018. The search strategy used to explore the database was as follows: ((()((((Photon induced photoacoustic streaming) OR Photon initiated photoacoustic streaming) OR Laser activated irrigation) OR Er: YAG laser) OR Sodium hypochlorite irrigation) OR Irrigation solution) OR Photoacoustic streaming) OR Hypochlorite sodium Er YAG). Articles that resulted from the above search strategy were first screened based on the title and abstract. In the second screening, whole articles were read, and articles were excluded based on predetermined exclusion criteria.

Screening and Selection of the Studies

The titles identified by the searches were screened first. If the title indicated possible inclusion, then the abstract was evaluated. In case of any doubt, the full text of the article was read. Following the evaluation of the abstracts, the articles considered eligible for the review were identified, and all of the full-text articles were assessed. Two independent reviewers assessed all the citations. Studies were selected for inclusion if they fulfilled all of the following criteria: a study about endodontic irrigation, a study about the LAI technique, and a study about PIPS. The exclusion criteria of this review were as follows:

1. Study on a plastic bloc simulating the root canal system; 2. Study on non-human teeth;

3. Study on an Er:YAG laser without using PIPS or LAI techniques;

4. Study on Er,Cr:YSGG, diode and neodymium lasers without comparison with an Er:YAG laser;

5. Article not in English.

\section{Data Extraction}

Data extraction for the included studies used a data extraction form designed to summarize each study. Data were extracted by one reviewer directly from the full text, and a second reviewer independently verified the extracted data. The following variables were recorded: author information, year of publication, type of teeth, type of laser, number of teeth employed, master apical file, type of laser tip, laser settings, activation time, and concentration of irrigant solutions. Each study was analyzed in terms of similarities so that a meta-analysis could be performed. However, a meta-analysis was not 
indicated because of the considerable methodological heterogeneity. Rather, a descriptive analysis of the results of the individual studies was undertaken.

Quality Assessment (Risk of Bias)

The quality of each selected study was evaluated based on the following criteria:

(1) Was the calculation of an adequate sample size performed before starting the experiments?

(2) Were the teeth preparations performed by one operator?

(3) Was the teeth preparation procedure standardized?

(4) Were the teeth randomly divided into groups?

(5) Was the irrigating procedure performed by one operator?

(6) Were the same irrigants used in the control groups and test groups?

(7) Was the experience of the operator on the PIPS and LAI techniques reported?

(8) Were the analyses performed by evaluators blinded to the groups?

After collecting these items, the studies were classified with a high, moderate, or low risk of bias. Studies that failed to report five or more of the above items were classified as high risk, studies that failed to report three or four items were classified as moderate risk, and studies that failed to report two items or less were classified as low risk.

\section{Results}

The PubMed database yielded 343 citations in the first screening (title and abstract reviewing) process; 218 articles were selected according to the exclusion criteria, and 125 articles were subjected to full text review for eligibility assessment with 66 additional articles excluded during that process. The final result was the inclusion of 59 articles for this review (Figure 1).

\section{Outcomes and Interests}

The 59 articles included in this review were published between 2008 and 2018. Teeth used in the studies are extracted monoradicular human teeth that are generally decoronated to have the same working length. They are instrumented by different file systems and are particularly prepared for each study, including creating artificial intracanal irregularities, incubating microorganisms, cutting in half, and so on. They received different irrigation protocols before being analyzed by optical, confocal, or electronic microscopy. To evaluate the results of these articles, we established the analysis criteria for this review as follows:

1. Root canal disinfection and debris removal

2. Smear layer removal

3. Root canal medication and sealer removal

4. Resin sealer bond strength

5. Dentinal tubule penetration

6. Apical extrusion
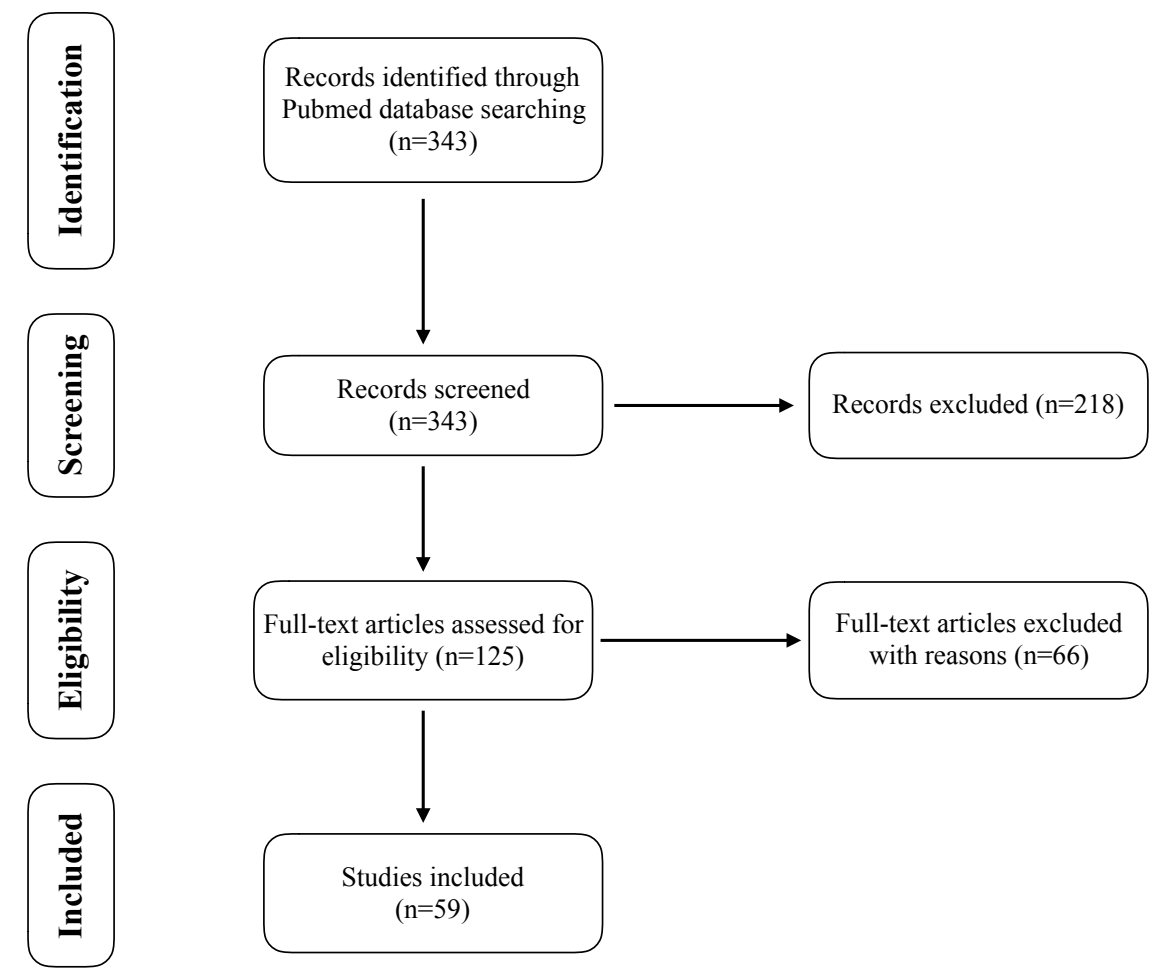

Figure 1. Articles Selection Flow Chart. 


\section{Risk of Bias}

All 59 included studies were assessed for the risk of bias (Table 1$)$, and only 4 (7\%) showed a low risk of bias. Ten (17\%) had a high risk. Most studies, 45 (76\%), had a medium risk.

\section{Debris Removal}

There were 11 studies that discussed debris removal. Four of them concluded that LAI was more effective than other methods in removing dentine debris from root canals. All four studies found that the PIPS and LAI techniques are significantly more efficient to eliminate debris than conventional syringe irrigation (CSI) alone. Three studies also concluded that the PIPS and LAI techniques remove significantly more apical dentinal debris than passive ultrasonic irrigation (PUI). ${ }^{22-24}$ Arslan et $\mathrm{al}^{24}$ showed that PIPS is significantly more efficient than EndoActivator.

The authors of the other seven studies found no significantly greater debridement efficacy of PIPS versus Er: YAG LAI or other techniques. They concluded that there is no difference between the LAI technique and/ or PIPS groups and PUI, ${ }^{25}$ EndoVac, ${ }^{26}$ ultrasonicallyactivated irrigation (UAI), ${ }^{27-29}$ manual-activated irrigation (MAI), ${ }^{29}$ or CSI. ${ }^{26,27}$ Two articles reported that LAI with an Er: YAG laser eliminated significantly more debris than PIPS (Table 2). ${ }^{25,30}$

\section{Canal Disinfection}

Eighteen studies addressed canal disinfection. Two-thirds of them $(11 / 18)$ concluded that PIPS had high bacterial killing efficacy, which was significantly more effective than CSI. ${ }^{31-40}$ This was also more effective than several other activation techniques including PUI, ${ }^{31,35} \mathrm{Nd}$ :YAG irradiation, ${ }^{39}$ EndoActivator, and XP-endo Finisher file. ${ }^{37}$ One study found that PIPS coupled with $6 \% \mathrm{NaOCl}$ inhibited $100 \%$ of E. faecalis but did not compare it to other techniques. ${ }^{41}$

Seven other studies showed no significant improvement in bacterial eradication following the activation by PIPS. The results were tested and compared to CSI, ${ }^{42-44}$ diode laser irradiation, ${ }^{45} \mathrm{PUI},{ }^{44} \mathrm{UAI},{ }^{46}$ and Er,Cr:YSGG LAI. $^{47}$ One study varied the laser settings and $\mathrm{NaOCl}$ concentration and concluded that the decontamination was only efficient with $5 \% \mathrm{NaOCl}$ and no irrigation protocol other than PIPS (Table 2). ${ }^{48}$

\section{Smear Layer Removal}

Seventeen studies were included in the analysis of smear layer removal. Seven remarked on better smear layer removal following Er:YAG laser treatment. The authors noticed that Er:YAG lasers were significantly more effective than Nd:YAG LAI and MAI, ${ }^{49}$ PUI, ${ }^{50,51}$ diode lasers, ${ }^{52}$ and CSI. ${ }^{30,50,52,53}$ They also had better results than ANP (EndoVac), Nd:YAG LAI, and self-adjusting file (SAF) ${ }^{30,52}$ but this improvement was not statistically significant. Irrigation with $\mathrm{NaOCl}$ and EDTA activated by lasers was significantly better versus $\mathrm{NaOCl}$ activated alone, EDTA activated alone, and unactivated EDTA alone. ${ }^{54}$

The remaining studies showed no superiority of the Er:YAG laser in removing smear layers from root canals versus other techniques including the EndoActivator, ${ }^{55,56}$ EndoVac, ${ }^{26,56,57}$ LAI (Nd:YAG, Er,Cr:YSGG), ${ }^{58}$ and CSI. ${ }^{26,43,59}$ Despite this, three studies still found that PIPS was better than CSI. ${ }^{55,57,58}$ The rest only tested PIPS or LAI and did not compare them with other techniques (Table 3). ${ }^{19,20,60}$

Root Canal Medication and Sealer Removal

All four studies involving this subject remarked that the use of Er:YAG as PIPS or LAI improved the results. LAI or PIPS produced similar results to PUI in two studies ${ }^{61,62}$ and better ones in two other studies. ${ }^{63,64}$ They also performed better than EndoActivator, ${ }^{61,63}$ XP-endo Finisher file, and CanalBrush. ${ }^{62}$ They gave better results than CSI in all four studies (Table 4).

\section{Root Canal Sealer Bond Strength}

We included seven studies here. Four of them remarked on higher bond strength of resin sealers following PIPS. PIPS was reported to give significantly better results compared to CSI ${ }^{65-68}$ and UAI. ${ }^{67}$ It performed as effectively as PUI in two studies ${ }^{65,69}$ but better in one study. ${ }^{66}$ In the latter, PIPS outperformed LAI (Er:YAG, Nd:YAG, diode lasers), PUI, and EndoVac. Nevertheless, the three other studies did not remark on the improved penetration caused by PIPS versus CSI, ${ }^{26,70} \mathrm{MAI},{ }^{71}$ and EndoVac (Table 5). ${ }^{26}$

\section{Irrigant Penetration in Dentinal Tubules}

Only one study ${ }^{69}$ was found on irrigant penetration into dentinal tubules. The authors concluded that PIPS led to a significantly improved penetration area versus PUI, EndoActivator, and CSI (Table 6).

\section{Apical Extrusion}

Three out of five studies concluded that PIPS and Er:YAG LAI produce more extrusion than all other irrigation methods except for CSI in one study. ${ }^{72}$ Irrigation systems included EndoVac, EndoActivator, XP-endo Finisher file, and CSI. ${ }^{72-74}$ The two remaining studies concluded that laser activation produced statistically similar amounts of extrusion to UAI and CSI and more than the side-vented needle (Table 7). ${ }^{24,75}$

\section{Discussion}

PIPS and LAI techniques are described in the literature as a revolutionary and powerful method to activate the irrigant. These tools use the photothermal effect of direct irradiation as well as the photoacoustic effect. The main advantage is to overcome unwanted effects on the carbonization of the root canal dentin. PIPS studies tend to replace the LAI technique. In fact, 17 of the 55 articles 


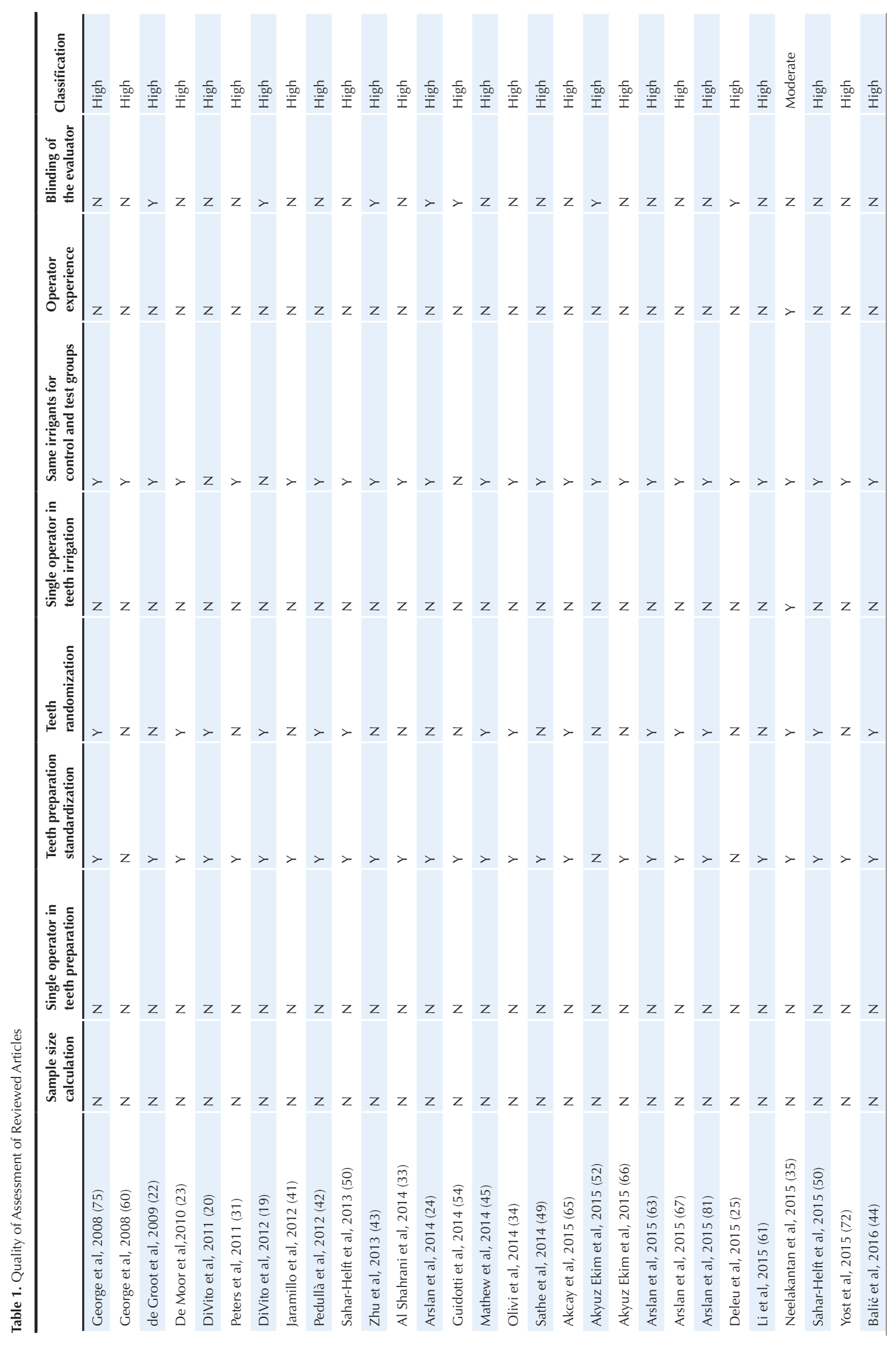




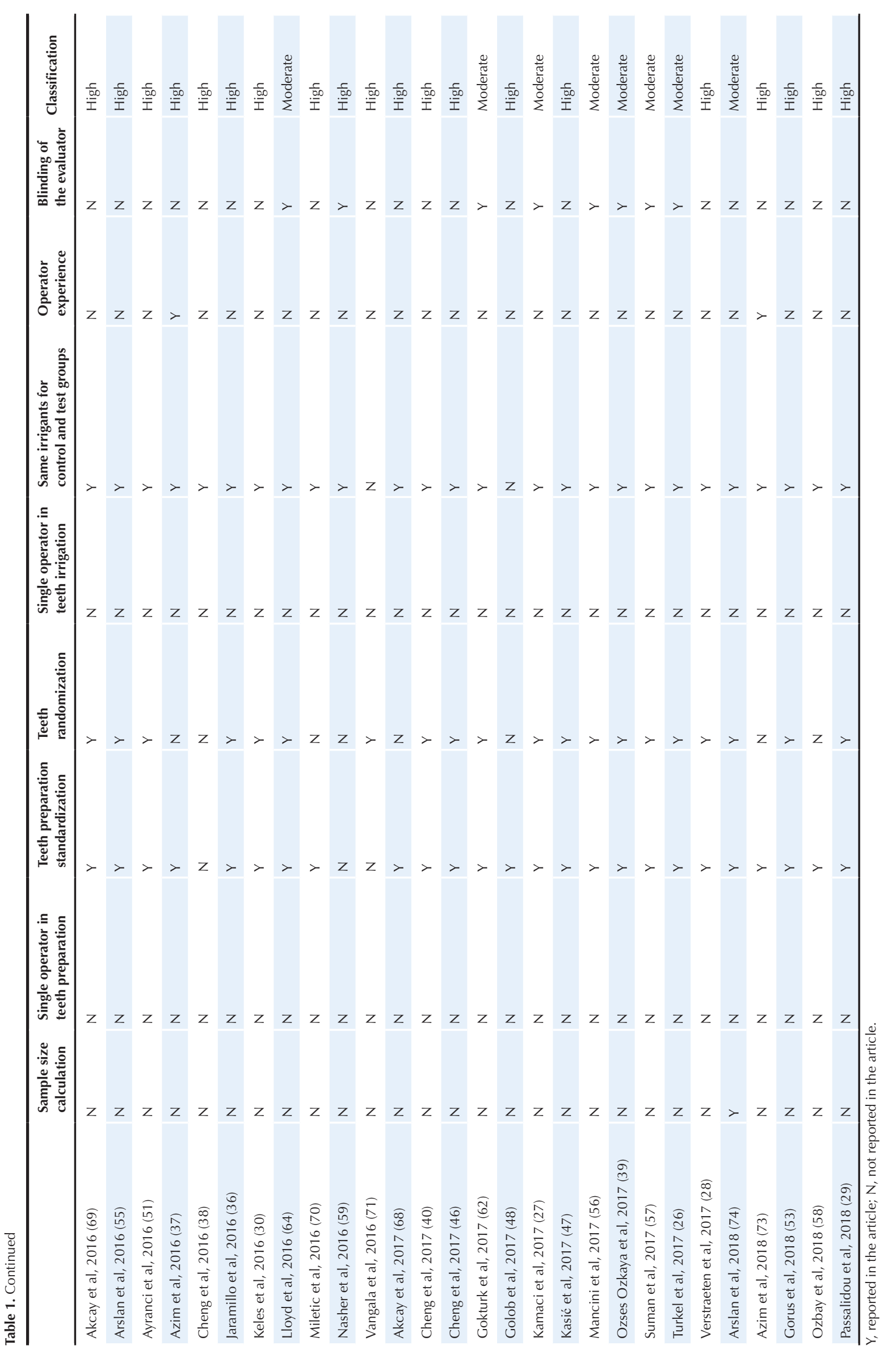




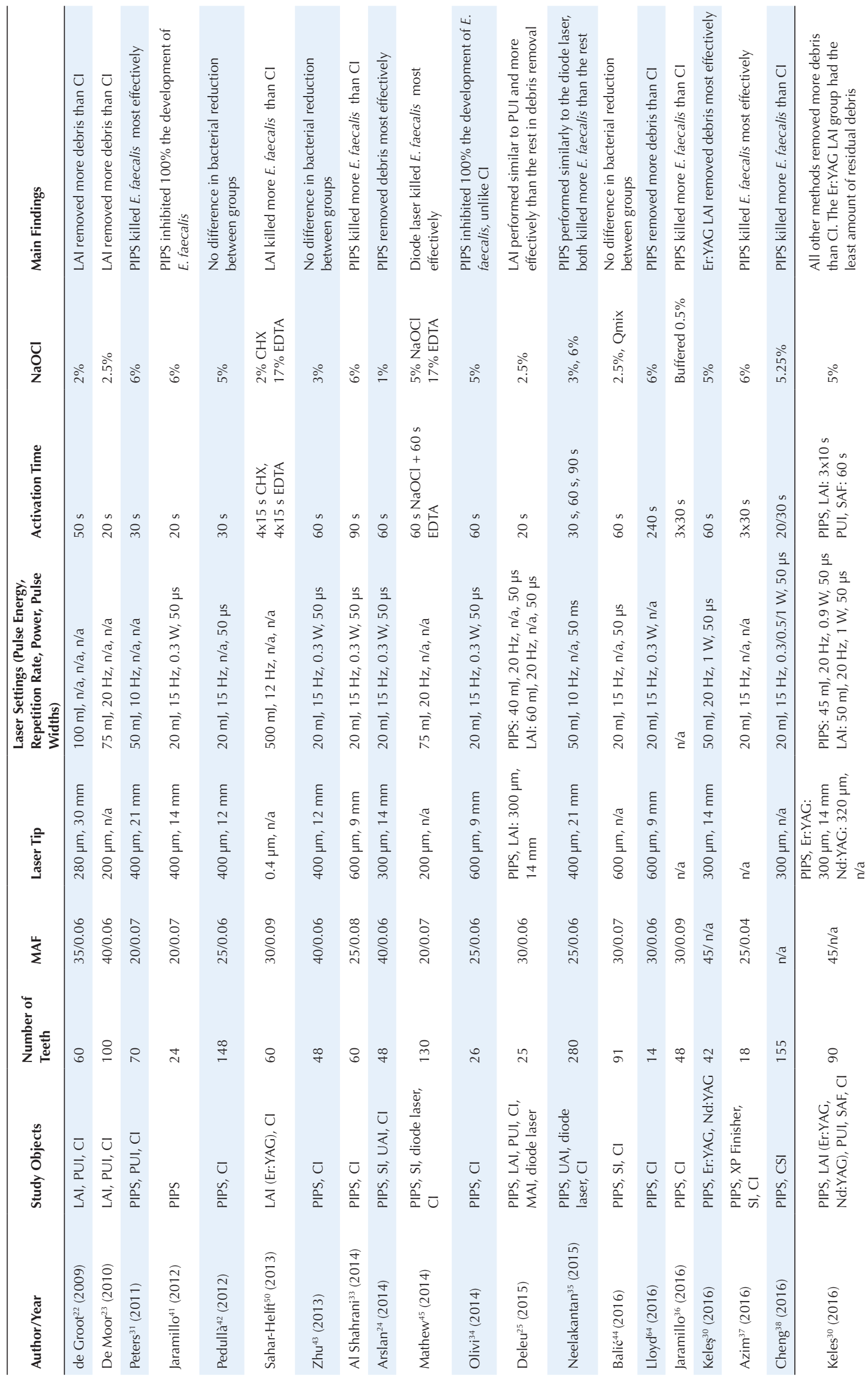




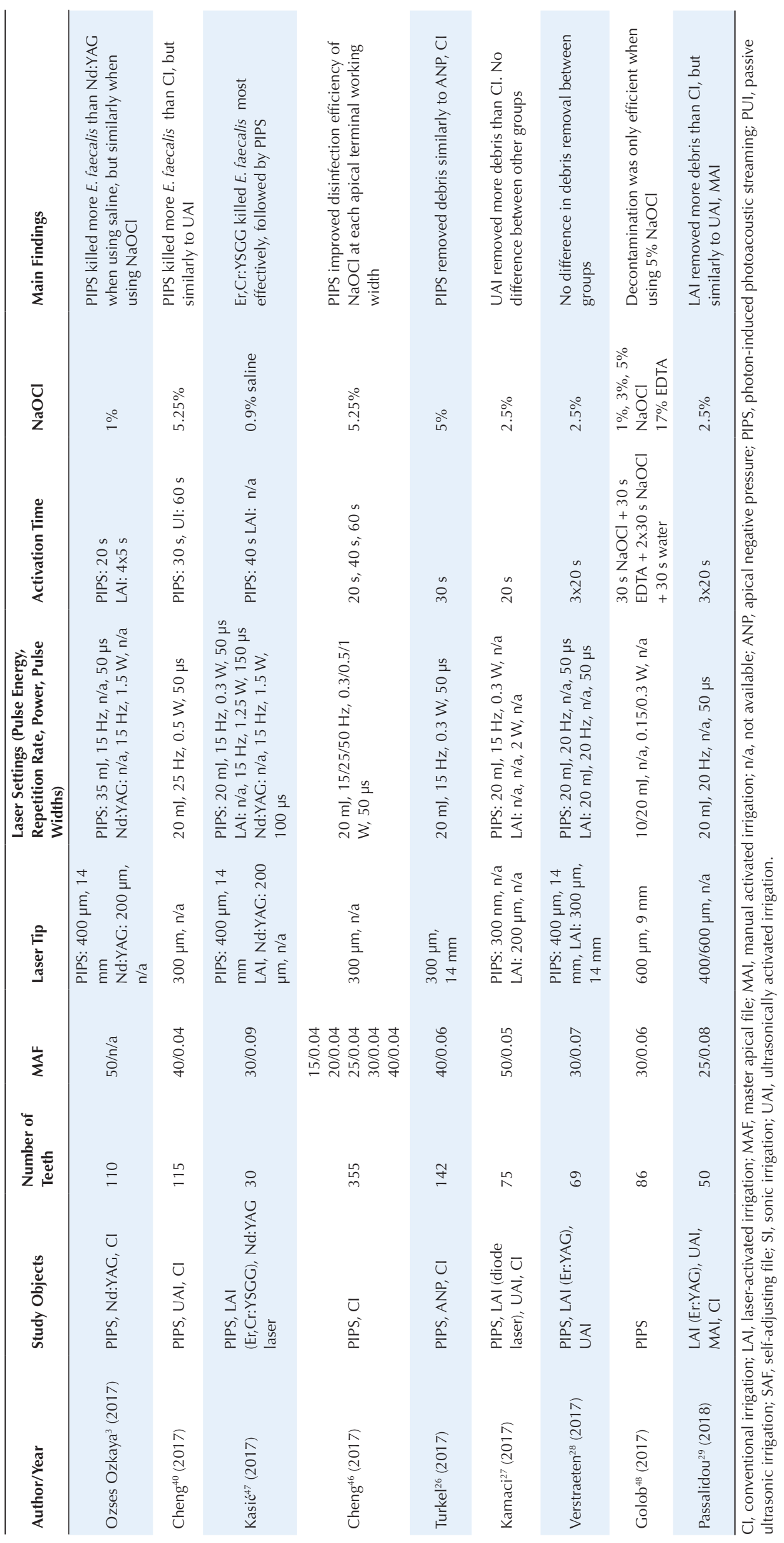




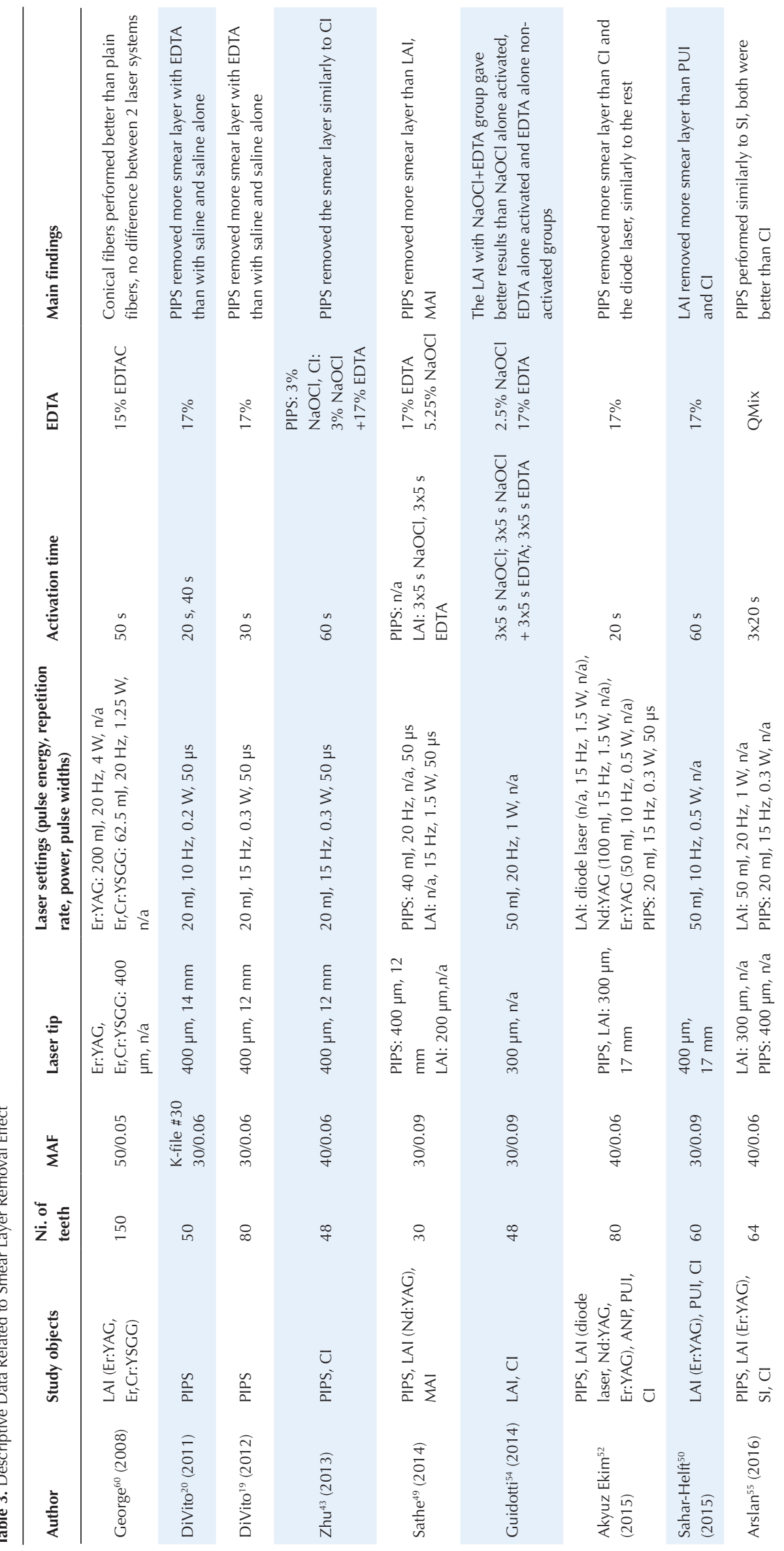




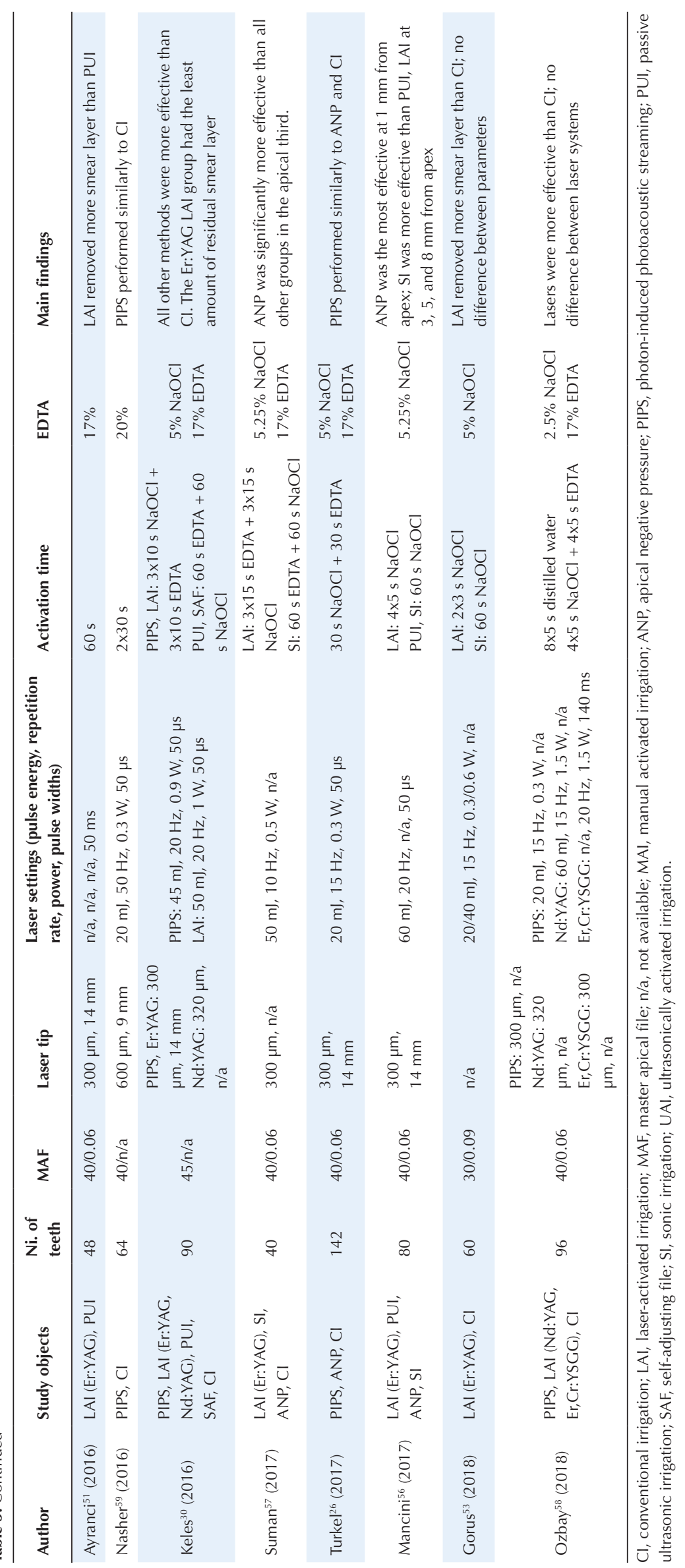


Table 4. Descriptive Data Related to Calcium Hydroxide Removal Effect

\begin{tabular}{|c|c|c|c|c|c|c|c|c|}
\hline Author & Study Objects & $\begin{array}{l}\text { No. of } \\
\text { Teeth }\end{array}$ & MAF & Laser Tip & $\begin{array}{l}\text { Laser Settings (Pulse } \\
\text { Energy, Repetition Rate, } \\
\text { Power, Pulse Widths) }\end{array}$ & Activation Time & Irrigant & Main Findings \\
\hline $\begin{array}{l}\text { Arslan }^{63} \\
(2015)\end{array}$ & PIPS, UAI, SI, CI & 48 & $40 / 0.06$ & $\begin{array}{l}300 \mu \mathrm{m}, \\
14 \mathrm{~mm}\end{array}$ & $30 \mathrm{~mJ}, 30 \mathrm{~Hz}, 0.9 \mathrm{~W}, \mathrm{n} / \mathrm{a}$ & $\begin{array}{l}\text { PIIPS, UAI: } 3 \times 20 \mathrm{~s} \\
\text { SI: } 60 \mathrm{~s}\end{array}$ & $17 \%$ EDTA & $\begin{array}{l}\text { PIPS performed } \\
\text { most effectively }\end{array}$ \\
\hline $\mathrm{Li}^{61}(2015)$ & PIPS, UAI, SI, CI & 24 & $25 / 0.08$ & $\begin{array}{l}300 \mu \mathrm{m}, \\
14 \mathrm{~mm}\end{array}$ & $20 \mathrm{~mJ}, 15 \mathrm{~Hz}, 0.3 \mathrm{~W}, \mathrm{n} / \mathrm{a}$ & $3 \times 20 \mathrm{~s}$ & $3 \% \mathrm{NaOCl}$ & $\begin{array}{l}\text { PIPS and PUI } \\
\text { performed } \\
\text { similarly, better } \\
\text { than the rest }\end{array}$ \\
\hline $\begin{array}{l}\text { Lloyd }^{64} \\
(2016)\end{array}$ & PIPS, PUI, CI & 30 & $25 / 0.06$ & $\begin{array}{l}600 \mu \mathrm{m}, \\
9 \mathrm{~mm}\end{array}$ & $20 \mathrm{~mJ}, 15 \mathrm{~Hz}, \mathrm{n} / \mathrm{a}, \mathrm{n} / \mathrm{a}$ & $\begin{array}{l}3 \times 30 \text { s } \mathrm{NaOCl}+ \\
30 \text { s EDTA }\end{array}$ & $\begin{array}{l}8.25 \% \\
\mathrm{NaOCl} \\
17 \% \text { EDTA }\end{array}$ & $\begin{array}{l}\text { PIPS performed } \\
\text { most effectively }\end{array}$ \\
\hline $\begin{array}{l}\text { Gokturk }^{62} \\
(2017)\end{array}$ & $\begin{array}{l}\text { LAI (Er:YAG), PUI, } \\
\text { SI, XP Finisher, } \\
\text { CanalBrush, Cl } \\
\text { (beveled needle, } \\
\text { double side-vented } \\
\text { needle) }\end{array}$ & 105 & $40 / 0.06$ & $\begin{array}{l}\text { ISO 30, } \\
28 \mathrm{~mm}\end{array}$ & $100 \mathrm{~mJ}, 10 \mathrm{~Hz}, 1 \mathrm{~W}, \mathrm{n} / \mathrm{a}$ & $\begin{array}{l}\text { LAI, PUI, } \\
\text { XP Finisher, } \\
\text { CanalBrush: } 60 \mathrm{~s} \\
\text { SI: } 120 \mathrm{~s}\end{array}$ & $2.5 \% \mathrm{NaOCl}$ & $\begin{array}{l}\mathrm{LAI} \text { and PUI } \\
\text { performed } \\
\text { similarly, better } \\
\text { than the rest }\end{array}$ \\
\hline
\end{tabular}

$\mathrm{Cl}$, conventional irrigation; LAI, laser activated irrigation; MAF, master apical file; n/a, not available; ANP, apical negative pressure; PIPS, photon-induced photoacoustic streaming; PUI, passive ultrasonic irrigation; SI, sonic irrigation; UAI, ultrasonically activated irrigation.

published since 2011 (year of the first PIPS article) cover the LAI technique.

This review shows heterogeneity in the protocols tested: laser fiber parameters, laser parameters, irrigant concentration, activation time, and the number of activation cycles. There are also differences in sample preparation: the type of the teeth, the state of the teeth (freshly extracted or coming from a collection), the teeth preparation protocol, incubation methods, bacterial counting methods, and analysis methods. Other factors such as the experience of the operators and the differences in irrigant use between test and control groups can also affect the results.

We found that 11 of 18 articles concluded that the Er:YAG laser benefited the activation procedure as judged by disinfection outcomes. However, there is little evidence in terms of evidence-based medicine because these studies were in vitro or ex vivo studies. The teeth were only infected with E. faecalis. The clinical reality is a poly-microbial infection, even including fungi. To date, no experimental in vitro model has reproduced endodontic biofilms. ${ }^{76}$ Its elimination via the PIPS or LAI technique has never been explored. In addition, some studies $^{19,20,41,48,60}$ only examined the LAI technique or PIPS without comparison to other techniques. The absence of in vivo studies or clinical trials reduces the scientific power of the Er:YAG laser for the activation of irrigating solutions. Additional clinical research studies, especially in vivo studies, are required to prove the scientific efficacy of these techniques and establish a sufficient level of proof.

Another factor to be considered is the irrigating solutions. Three major irrigants were used: $\mathrm{NaOCl}$, EDTA, and QMix. There is a large variety in the concentration of NaOCl: $1 \%, 2 \%, 2.5 \%, 3 \%, 5 \%, 5.25 \%$, and $6 \%$. The $2.5 \%$
$\mathrm{NaOCl}$ was found to be better due to its higher efficiency and lower cytotoxicity. ${ }^{77}$ However, $6 \% \mathrm{NaOCl}$ was shown to be the most effective disinfecting solution against a 3-week-old E. faecalis biofilm. ${ }^{78}$ The articles used various incubation times to evaluate the effectiveness of E. faecalis disinfection protocols: 2 weeks, 3 weeks, and 4 weeks. Other authors found that the E. faecalis biofilm was not completely established until 3 weeks. ${ }^{76}$

We only found consensus in the results on the removal of root canal medication and sealer-all studies remarked that the use of the Er:YAG laser improved the results versus other removal methods. Many factors such as the variation in sample conditions, irrigating protocols, and irrigating solutions hamper direct comparison of the results of the studies. The lack of concrete scientific proof makes it difficult to draw broad conclusions about the effectiveness of PIPS and LAI.

Nevertheless, we conclude that irrigation is a key element of endodontic success. The PIPS technique is a time-saving tool for clinicians. An important advantage of this technique is that the irrigant is propelled throughout the entire root canal system. Thus, we should discuss the results to establish a complete operating protocol and prognosis for treated teeth.

There are no clear recommendations in the literature about irrigation or activation times. ${ }^{35}$ The duration of the application should be as short as possible but with maximum efficiency. There is no consensus on application time. We noted a wide variety of activation times from 20 seconds to 240 seconds; none of the articles reviewed worked to create a reproducible protocol.

A complete clinical protocol for the final rinse was first suggested in 2012. ${ }^{79}$ The protocol is three cycles of 30 -second activation by PIPS with $\mathrm{NaOCl}$ followed 


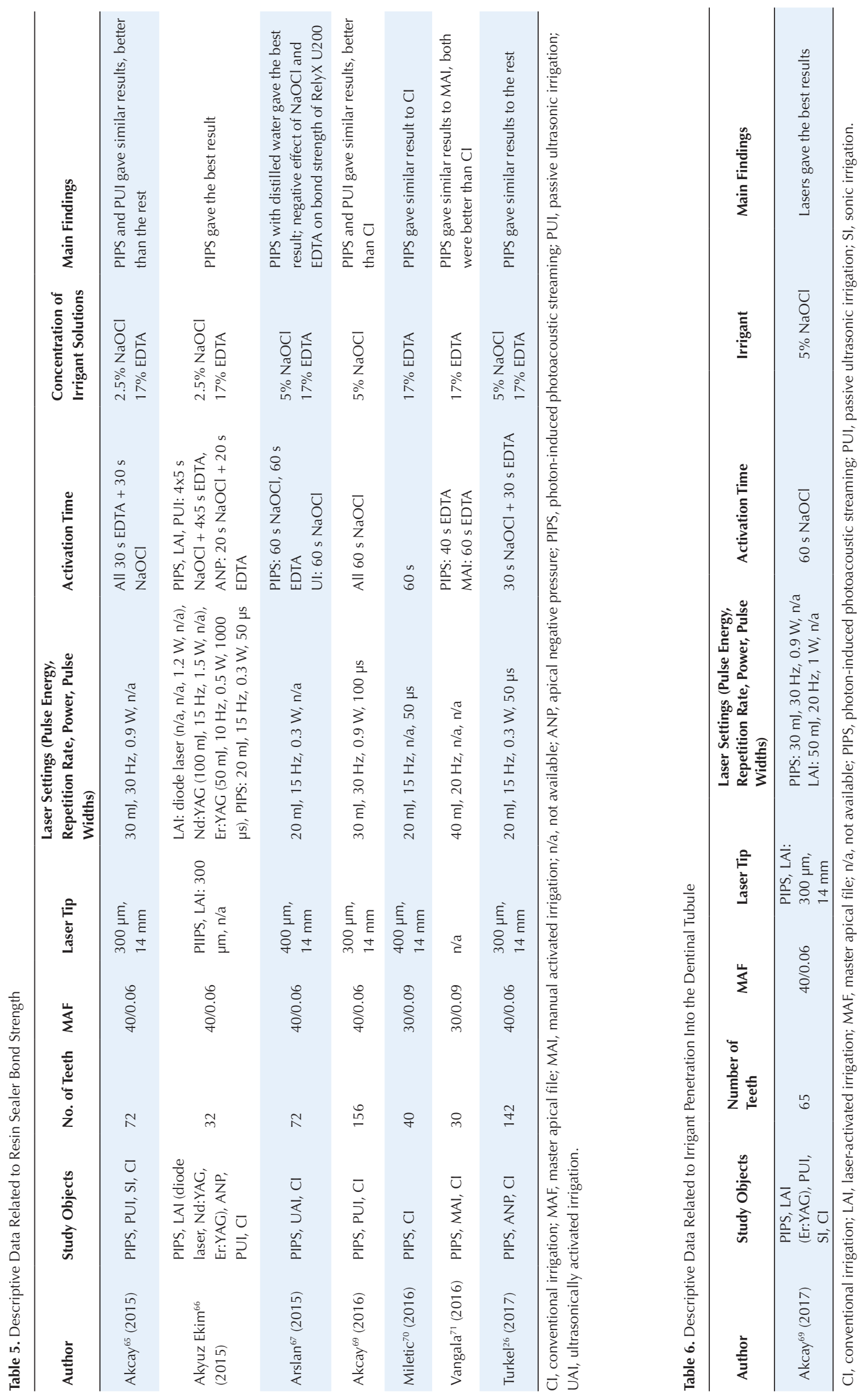


Table 7. Descriptive Data Related to Apical Extrusion Effect

\begin{tabular}{|c|c|c|c|c|c|c|c|c|}
\hline Author & Study Objects & $\begin{array}{l}\text { No. of } \\
\text { Teeth }\end{array}$ & MAF & Laser Tip & $\begin{array}{l}\text { Laser Settings (Pulse Energy, } \\
\text { Repetition Rate, Power, Pulse } \\
\text { Widths) }\end{array}$ & $\begin{array}{l}\text { Activation } \\
\text { Time }\end{array}$ & Irrigants & Main Findings \\
\hline $\begin{array}{l}\text { George }^{75} \\
(2008)\end{array}$ & $\begin{array}{l}\text { LAI (Er:YAG, } \\
\text { Er,Cr:YSGG), Cl }\end{array}$ & 16 & $50 / 0.05$ & $\begin{array}{l}400 \mu \mathrm{m}, \\
\mathrm{n} / \mathrm{a}\end{array}$ & $\begin{array}{l}\text { Er:YAG: } 200 \mathrm{~mJ}, \mathrm{n} / \mathrm{a}, 4 \mathrm{~W}, 50 \\
\text { ms; Er,Cr:YSGG: } 62.5 \mathrm{~mJ}, \mathrm{n} / \mathrm{a} \text {, } \\
1.25 \mathrm{~W}, 50 \mathrm{~ms}\end{array}$ & $5 \mathrm{~s}$ & Dye & $\begin{array}{l}\text { The volume of extruded fluid } \\
\text { was similar to conven- tional } \\
25-G \text { needles, but the fluid } \\
\text { was distributed further from } \\
\text { the apex }\end{array}$ \\
\hline $\begin{array}{l}\text { Arslan }^{81} \\
(2015)\end{array}$ & PIPS, UAI, Cl & 64 & $30 / 0.09$ & $\begin{array}{l}300 \mu \mathrm{m}, \\
14 \mathrm{~mm}\end{array}$ & $\begin{array}{l}20 \mathrm{~mJ}, 15 \mathrm{~Hz}, 0.3 \mathrm{~W}, 50 \mu \mathrm{s} ; \\
30 \mathrm{~mJ}, 30 \mathrm{~Hz}, 0.9 \mathrm{~W}, 50 \mu \mathrm{s}\end{array}$ & $30 \mathrm{~s}$ & $1 \% \mathrm{Na} \mathrm{OCl}$ & $\begin{array}{l}\text { PIPS at both } 0.3 \mathrm{~W} \text { and } 0.9 \\
\text { W resulted in similar solution } \\
\text { extrusion to the conventional } \\
\text { irrigation or ultrasonic } \\
\text { irrigation }\end{array}$ \\
\hline $\begin{array}{l}\text { Yost }^{72} \\
(2015)\end{array}$ & PIPS, ANP, SI, CI & 36 & $\begin{array}{l}35 / 0.04 \\
55 / 0.04\end{array}$ & $\begin{array}{l}600 \mu \mathrm{m}, \\
9 \mathrm{~mm}\end{array}$ & $\begin{array}{l}20 \mathrm{~mJ}, 15 \mathrm{~Hz}, \mathrm{n} / \mathrm{a}, 50 \mu \mathrm{s} \\
10 \mathrm{~mJ}, 15 \mathrm{~Hz}, \mathrm{n} / \mathrm{a}, 50 \mu \mathrm{s}\end{array}$ & $\begin{array}{l}\text { PIPS: } \\
3 \times 30 \mathrm{~s} \\
\text { SI: } 60 \mathrm{~s}\end{array}$ & $6 \% \mathrm{NaOCl}$ & $\begin{array}{l}\text { No difference was found } \\
\text { between the } 10 \mathrm{~mJ} \text { and } 20 \mathrm{~mJ} \\
\text { PIPS laser groups. EndoVac } \\
\text { demonstrated significantly less } \\
\text { potential for apical extrusion } \\
\text { than PIPS and Max-i-Probe }\end{array}$ \\
\hline $\begin{array}{l}\text { Arslan }^{74} \\
(2018)\end{array}$ & PIPS, Cl & 60 & $25 / 0.06$ & $\begin{array}{l}300 \mu \mathrm{m}, \\
14 \mathrm{~mm}\end{array}$ & $20 \mathrm{~mJ}, 15 \mathrm{~Hz}, 0.3 \mathrm{~W}, 50 \mu \mathrm{s}$ & $20 \mathrm{~s}$ & $\begin{array}{l}\text { bidistilled } \\
\text { water }\end{array}$ & $\begin{array}{l}\text { PIPS activation was associated } \\
\text { with significantly more } \\
\text { extrusion debris in curved } \\
\text { canals compared with no } \\
\text { activation }\end{array}$ \\
\hline $\begin{array}{l}\text { Azim }^{73} \\
(2018)\end{array}$ & $\begin{array}{l}\text { PIPS, ANP, XP } \\
\text { Finisher, SI, CI }\end{array}$ & 20 & $40 / 0.04$ & $\mathrm{n} / \mathrm{a}$ & $20 \mathrm{~mJ}, 15 \mathrm{~Hz}, \mathrm{n} / \mathrm{a}, \mathrm{n} / \mathrm{a}$ & $3 \times 30 \mathrm{~s}$ & $3 \% \mathrm{NaOCl}$ & $\begin{array}{l}\text { PIPS extrudes more irrigant } \\
\text { than other systems }\end{array}$ \\
\hline
\end{tabular}

$\mathrm{Cl}$, conventional irrigation; LAI, laser-activated irrigation; MAF, master apical file; n/a, not available; ANP, apical negative pressure; PIPS, photon-induced photoacoustic streaming; $\mathrm{SI}$, sonic irrigation; UAI, ultrasonically activated irrigation.

by three rounds of 30 -second off cycles. The next step is 30 seconds of irrigation using PIPS with water only. EDTA is then used with PIPS for 30 seconds, and finally, a 30-second cycle with PIPS and water is applied. One publication also tested this effectiveness and concluded that this protocol was the most effective compared to CI and PUI. ${ }^{64}$

Several laser parameters are also important. Meire et al reported that greater energy ( $40 \mathrm{~mJ}$ compared to 10 and $20 \mathrm{~mJ}$ ) coupled with $30 \mathrm{~Hz}$ of frequency eliminates more root canal debris. There are more powerful photoacoustic shockwaves at higher powers. ${ }^{80}$ We note that the energy used for the LAI technique can go up to $500 \mathrm{~mJ}^{32}$ with $4 \mathrm{~W}$ of power. ${ }^{60,75}$ However, no other publication has reported such parameters. Moreover, recently published articles showed that this technique used parameters close to those of PIPS. The use of PIPS at the $20 \mathrm{~mJ} / 0.3 \mathrm{~W}$ setting was reported to be effective in removing the smear layer without any damage to the dentinal tissue. ${ }^{19}$ Cheng et al also tested the Er:YAG laser at 0.3, 0.5, and 1.0 W for either 20 or 30 seconds. They concluded that the most efficient methods were activation with 0.5 and $1.0 \mathrm{~W}$ for 30 seconds. ${ }^{38}$ Laser activation at $0.5 \mathrm{~W}$ for 30 seconds combined with $\mathrm{NaOCl}$ is the preferable option because of the lower emission power. In addition, PIPS used at either 10 or $20 \mathrm{~mJ}$ and 0.3 or $0.9 \mathrm{~W}$ produced a similar apical extrusion volume. ${ }^{72,81}$ It would be interesting to test these parameters in clinical situations by exploring postoperative pain differences. ${ }^{82}$

\section{Conclusion}

In the field of endodontics, PIPS and Laser activated irrigation are described in the literature as a revolutionary and powerful method to activate the irrigant. The aim of this study was to review previously published studies and evaluate the effectiveness of Er:YAG LAI with PIPS versus other currently used methods and techniques in endodontic irrigation. There was a great variety in the study designs including bacterial incubation time, laser parameters, irrigation protocols, and irrigating solution used. The evidence suggests that Er:YAG LAI and PIPS are promising in canal disinfection as well as debris and smear layer removal. However, the large variety in the study methods makes the results less significant. Further studies are needed to better evaluate the efficiency of these techniques, especially in vivo studies.

\section{Ethical Considerations}

Not applicable.

\section{Conflict of Interests}

The authors declare no conflict of interest.

\section{References}

1. Haapasalo M, Shen Y, Wang Z, Gao Y. Irrigation in endodontics. Br Dent J. 2014;216(6):299-303. doi:10.1038/ 
sj.bdj.2014.204.

2. Kandaswamy D, Venkateshbabu N. Root canal irrigants. J Conserv Dent. 2010;13(4):256-264. doi:10.4103/09720707.73378.

3. Peters OA, Laib A, Göhring TN, Barbakow F. Changes in root canal geometry after preparation assessed by highresolution computed tomography. J Endod. 2001;27(1):1-6. doi: 10.1097/00004770-200101000-00001.

4. Moorer WR, Wesselink PR. Factors promoting the tissue dissolving capability of sodium hypochlorite. Int Endod J. 1982;15(4):187-196. doi:10.1111/j.1365-2591.1982. tb01277.x.

5. Abbott P V. Medicaments: aids to success in endodontics. Part 1. A review of the literature. Aust Dent J. 1990;35(5):438448. doi: 10.1111/j.1834-7819.1990.tb05427.x.

6. Zehnder M. Root Canal Irrigants. J Endod. 2006;32(5):389398. doi:10.1016/j.joen.2005.09.014.

7. Mohammadi Z, Shalavi S, Yaripour S, Kinoshita JI, Manabe A, Kobayashi M, et al, Smear layer removing ability of root canal irrigation solutions: a review. J Contemp Dent Pract. 2019;20(3):395-402.

8. Loel DA. Use of acid cleanser in endodontic therapy. $J$ Am Dent Assoc. 1975;90(1):148-151. doi:10.14219/jada. archive.1975.0010.

9. Yamaguchi $M$, Yoshida $K$, Suzuki R, Nakamura $H$. Root canal irrigation with citric acid solution. J Endod. 1996;22(1):27-29. doi:10.1016/S0099-2399(96)80232-9.

10. Torabinejad M, Handysides R, Khademi AA, Bakland LK. Clinical implications of the smear layer in endodontics: A review. Oral Surg Oral Med Oral Pathol Oral Radiol Endod. 2002;94(6):658-666. doi:10.1067/moe.2002.128962.

11. Kokkas AB, Boutsioukis AC, Vassiliadis LP, Stavrianos $\mathrm{CK}$. The influence of the smear layer on dentinal tubule penetration depth by three different root canal sealers: An in vitro study. J Endod. 2004;30(2):100-102. doi:10.1097/00004770-200402000-00009.

12. Rossi-Fedele G, Guastalli AR, Doğramaci EJ, Steier $\mathrm{L}$, De Figueiredo JA. Influence of $\mathrm{pH}$ changes on chlorine-containing endodontic irrigating solutions. Int Endod J. 2011;44(9):792-799. doi:10.1111/j.13652591.2011.01911.x.

13. Baumgartner JC, Ibay AC. The chemical reactions of irrigants used for root canal debridement. J Endod. 1987;13(2):47-51. doi:10.1016/S0099-2399(87)80153-X.

14. Grawehr M, Sener B, Waltimo T, Zehnder M. Interactions of ethylenediamine tetraacetic acid with sodium hypochlorite in aqueous solutions. Int Endod J. 2003;36(6):411-417. doi:10.1046/j.1365-2591.2003.00670.x.

15. Jiang LM, Lak B, Eijsvogels LM, Wesselink P, van der Sluis LW. Comparison of the cleaning efficacy of different final irrigation techniques. J Endod. 2012;38(6):838-841. doi:10.1016/j.joen.2012.03.002.

16. Diaci J, Gaspirc B. Comparison of Er:YAG and Er,Cr:YSGG lasers used in dentistry. J Laser Health Acad. 2012;2012(1):113.

17. Mir M, Gutknecht N, Poprawe R, Vanweersch L, Lampert F. Visualising the procedures in the influence of water on the ablation of dental hard tissue with erbium:yttriumaluminium-garnet and erbium, chromium:yttriumscandium-gallium-garnet laser pulses. Lasers Med Sci. 2009;24(3):365-374. doi:10.1007/s10103-008-0571-1.

18. Olivi G, DiVito E. Photoacoustic endodontics using PIPS: experimental background and clinical protocol. J Laser
Health Acad. 2012;2012(1):22-25.

19. DiVito E, Peters OA, Olivi G. Effectiveness of the erbium: YAG laser and new design radial and stripped tips in removing the smear layer after root canal instrumentation. Lasers Med Sci. 2012;27(2):273-280. doi:10.1007/s10103010-0858-x.

20. DiVito EE, Colonna MP, Olivi G. The Photoacoustic Efficacy of an Er:YAG Laser with Radial and Stripped Tips on Root Canal Dentin Walls: An SEM Evaluation. J Laser Dent. 2011;19(1):156-161.

21. Moher D, Shamseer L, Clarke M, Ghersi D, Liberati A, Petticrew M, et al Preferred reporting items for systematic review and meta-analysis protocols (PRISMA-P) 2015 statement. Syst Rev. 2015;4(1):1. doi:10.1186/2046-40534-1.

22. de Groot SD, Verhaagen B, Versluis M, Wu MK, Wesselink PR, van ders Sluis LW. Laser-activated irrigation within root canals: Cleaning efficacy and flow visualization. Int Endod J. 2009;42(12):1077-1083. doi:10.1111/j.13652591.2009.01634.x.

23. De Moor RJ, Meire M, Goharkhay K, Moritz A, Vanobbergen $\mathrm{J}$. Efficacy of ultrasonic versus laser-activated irrigation to remove artificially placed dentin debris plugs. J Endod. 2010;36(9):1580-1583. doi:10.1016/j.joen.2010.06.007.

24. Arslan H, Capar ID, Saygili G, Gok T, Akcay M. Effect of photon-initiated photoacoustic streaming on removal of apically placed dentinal debris. Int Endod J. 2014;47(11):1072-1077. doi:10.1111/iej.12251.

25. Deleu E, Meire MA, De Moor RJ. Efficacy of laserbased irrigant activation methods in removing debris from simulated root canal irregularities. Lasers Med Sci. 2015;30(2):831-835. doi:10.1007/s10103-013-1442-y.

26. Turkel E, Onay EO, Ungor M. Comparison of three final irrigation activation techniques: effects on canal cleanness, smear layer removal, and dentinal tubule penetration of two root canal sealers. Photomed Laser Surg. 2017;35(12):672681. doi:10.1089/pho.2016.4234.

27. Kamaci A, Aydin B, Erdilek N. The effect of ultrasonically activated irrigation and laser based root canal irrigation methods on debris removal. Int $J$ Artif Organs. 2018;41(2):71-75. doi:10.5301/ijao.5000646.

28. Verstraeten J, Jacquet W, De Moor RJ, Meire MA. Hard tissue debris removal from the mesial root canal system of mandibular molars with ultrasonically and laser-activated irrigation: a micro-computed tomography study. Lasers Med Sci. 2017;32(9):1965-1970. doi:10.1007/s10103-0172297-4.

29. Passalidou S, Calberson F, De Bruyne M, De Moor R, Meire MA. Debris removal from the mesial root canal system of mandibular molars with laser-activated irrigation. J Endod. 2018;44(11):1697-1701. doi:10.1016/j.joen.2018.06.007.

30. Keles A, Kamalak A, Keskin C, Akçay M, Uzun İ. The efficacy of laser, ultrasound and self-adjustable file in removing smear layer debris from oval root canals following retreatment: A scanning electron microscopy study. Aust Endod J. 2016;42(3):104-111. doi:10.1111/aej.12145.

31. Peters OA, Bardsley S, Fong J, Pandher G, Divito E. Disinfection of root canals with photon-initiated photoacoustic streaming. J Endod. 2011;37(7):1008-1012. doi:10.1016/j.joen.2011.03.016.

32. Sahar-Helft S, Stabholtz A, Moshonov J, Gutkin V, Redenski I, Steinberg D. Effect of Er:YAG laser-activated irrigation solution on Enterococcus faecalis biofilm in an ex-vivo root 
canal model. Photomed Laser Surg. 2013;31(7):334-341. doi:10.1089/pho.2012.3445.

33. Al Shahrani M, DiVito E, Hughes CV, Nathanson D, Huang GT. Enhanced removal of Enterococcus faecalis biofilms in the root canal using sodium hypochlorite plus photoninduced photoacoustic streaming: An in vitro study. Photomed Laser Surg. 2014;32(5):260-266. doi:10.1089/ pho.2014.3714.

34. Olivi G, DiVito E, Peters O, Kaitsas V, Angiero F, Signore A, et al, Disinfection efficacy of photon-induced photoacoustic streaming on root canals infected with Enterococcus faecalis: An ex vivo study. J Am Dent Assoc. 2014;145(8):843-848. doi:10.14219/jada.2014.46.

35. Neelakantan P, Cheng CQ, Mohanraj R, Sriraman P, Subbarao C, Sharma S. Antibiofilm activity of three irrigation protocols activated by ultrasonic, diode laser or Er:YAG laser in vitro. Int Endod J. 2015;48(6):602-610. doi:10.1111/iej.12354.

36. Jaramillo DE, Aguilar E, Arias A, Ordinola-Zapata R, Aprecio RM, Ibarrola JL. Root canal disinfection comparing conventional irrigation vs photon-induced photoacoustic streaming (PIPS) using a buffered 0.5 $\%$ sodium hypochlorite solution. Evid Based Endod. 2016;1(1):6. doi:10.1186/s41121-016-0006-6.

37. Azim AA, Aksel H, Zhuang T, Mashtare T, Babu JP, Huang GT. Efficacy of 4 irrigation protocols in killing bacteria colonized in dentinal tubules examined by a novel confocal laser scanning microscope analysis. J Endod. 2016;42(6):928-34. doi:10.1016/j.joen.2016.03.009.

38. Cheng X, Chen B, Qiu J, He W, Lv H, Qu T, et al, Bactericidal effect of Er:YAG laser combined with sodium hypochlorite irrigation against Enterococcus faecalis deep inside dentinal tubules in experimentally infected root canals. J Med Microbiol. 2016;65(2):176-187. doi:10.1099/jmm.0.000205.

39. Ozses Ozkaya B, Gulsahi K, Ungor M, Gocmen JS. A Comparison of Er:YAG laser with photon-initiated photoacoustic streaming, Nd:YAG laser, and conventional irrigation on the eradication of root dentinal tubule infection by Enterococcus faecalis Bbofilms: A Scanning electron microscopy study. Scanning. 2017;2017:6215482. doi: $10.1155 / 2017 / 6215482$

40. Cheng X, Xiang D, He W, Qiu J, Han B, Yu Q, et al, Bactericidal Effect of Er:YAG laser-activated sodium hypochlorite irrigation against biofilms of Enterococcus faecalis isolate from canal of root-filled teeth with periapical lesions. Photomed Laser Surg. 2017;35(7):386392. doi:10.1089/pho.2017.4293.

41. Jaramillo DE, Aprecio RM, Angelov N, Divito E. Efficacy of photon induced photoacoustic streaming (PIPS) on root canals infected with Enterococcus faecalis: A pilot study. Endod Prac. 2012;5(3):28-32.

42. Pedullà E, Genovese C, Campagna E, Tempera G, Rapisarda E. Decontamination efficacy of photon-initiated photoacoustic streaming (PIPS) of irrigants using lowenergy laser settings: An ex vivo study. Int Endod J. 2012;45:865-870. doi:10.1111/j.1365-2591.2012.02044.x.

43. Zhu X, Yin X, Chang JW, Wang Y, Cheung GS, Zhang C. Comparison of the Antibacterial effect and smear layer removal using photon-initiated photoacoustic streaming aided irrigation versus a conventional irrigation in singlerooted canals: An in vitro study. Photomed Laser Surg. 2013;31(8):371-377. doi:10.1089/pho.2013.3515.
44. Balić M, Lucić R, Mehadžić K, Bago I, Anić I, Jakovljević $\mathrm{S}$, et al, The efficacy of photon-initiated photoacoustic streaming and sonic-activated irrigation combined with QMiX solution or sodium hypochlorite against intracanal E. faecalis biofilm. Lasers Med Sci. 2016;31(2):335-342. doi:10.1007/s10103-015-1864-9.

45. Mathew J, Emil J, Paulaian B, John B, Raja J, Mathew J. Viability and antibacterial efficacy of four root canal disinfection techniques evaluated using confocal laser scanning microscopy. J Conserv Dent. 2014;17(5):444-448. doi:10.4103/0972-0707.139833.

46. Cheng X, Tian T, Tian Y, Xiang D, Qiu J, Liu X, et al, Erbium:yttrium aluminum garnet laser-activated sodium hypochlorite irrigation: A promising procedure for minimally invasive Endodontics. Photomed Laser Surg. 2017;35(12):695-701. doi:10.1089/pho.2017.4274.

47. Kasić S, Knezović M, Beader N, Gabrić D, Malčić AI, Baraba A. Efficacy of three different lasers on eradication of Enterococcus faecalis and Candida albicans biofilms in root canal system. Photomed Laser Surg. 2017;35(7):372377. doi:10.1089/pho.2016.4258.

48. Golob BS, Olivi G, Vrabec M, El Feghali R, Parker S, Benedicenti S. Efficacy of photon-induced photoacoustic streaming in the reduction of Enterococcus faecalis within the root canal: Different settings and different sodium hypochlorite concentrations. J Endod. 2017;43(10):17301735. doi:10.1016/j.joen.2017.05.019.

49. Sathe S, Hegde V, Jain PA, Ghunawat D. Effectiveness of Er: YAG (PIPS) and Nd: YAG activation on final irrigants for smear layer removal - SEM observation. J Dent Lasers. 2014;8(1):8-13. doi:10.4103/0976-2868.134110.

50. Sahar-Helft S, Sarp AS, Stabholtz A, Gutkin V, Redenski I, Steinberg D. Comparison of positive-pressure, passive ultrasonic, and laser-activated irrigations on smear-layer removal from the root canal surface. Photomed Laser Surg. 2015;33(3):129-135. doi:10.1089/pho.2014.3788.

51. Ayranci LB, Arslan H, Akcay M, Capar ID, Gok T, Saygili G. Effectiveness of laser-assisted irrigation and passive ultrasonic irrigation techniques on smear layer removal in middle and apical thirds. Scanning. 2016;38(2):121-127. doi:10.1002/sca.21247.

52. Akyuz Ekim SN, Erdemir A. Comparison of different irrigation activation techniques on smear layer removal: An in vitro study. Microsc Res Tech. 2015;78(3):230-239. doi:10.1002/jemt.22466.

53. Gorus Z. A comparative evaluation of smear layer removal by using different Er:YAG lasers parameters: an in-vitro scanning electron microscopic study. Niger J Clin Pract. 2018;21(12):1602-6.

54. Guidotti R, Merigo E, Fornaini C, Rocca JP, Medioni E, Vescovi P. Er:YAG 2,940-nm laser fiber in endodontic treatment: A help in removing smear layer. Lasers Med Sci. 2014;29(1):69-75. doi:10.1007/s10103-012-1217-x.

55. Arslan D, Guneser MB, Dincer AN, Kustarci A, Er K, Siso SH. Comparison of smear layer removal ability of QMix with different activation techniques. $J$ Endod. 2016;42(8):1279-1285. doi:10.1016/j.joen.2016.04.022.

56. Mancini M, Cerroni L, Iorio L, Dall'Asta L, Cianconi L. FESEM evaluation of smear layer removal using different irrigant activation methods (EndoActivator, EndoVac, PUI and LAI). An in vitro study. Clin Oral Investig. 2018;22(2):993-999. doi:10.1007/s00784-017-2179-y. 
57. Suman S, Verma P, Prakash-Tikku A, Bains R, KumarShakya V. A comparative evaluation of smear layer removal using apical negative pressure (EndoVac), sonic irrigation (EndoActivator) and Er:YAG laser -An in vitro SEM study. J Clin Exp Dent. 2017;9(8):e981-e987. doi:10.4317/ jced.53881.

58. Ozbay Y, Erdemir A. Effect of several laser systems on removal of smear layer with a variety of irrigation solutions. Microsc Res Tech. 2018;81(10):1214-1222. doi:10.1002/ jemt.23122.

59. Nasher R, Franzen R, Gutknecht N. The effectiveness of the Erbium:Yttrium aluminum garnet PIPS technique in comparison to different chemical solutions in removing the endodontic smear layer. An in vitro profilometric study. Lasers Med Sci. 2016;31(9):1871-1882. doi:10.1007/ s10103-016-2063-z.

60. George R, Meyers IA, Walsh LJ. Laser activation of endodontic irrigants with improved conical laser fiber tips for removing smear layer in the apical third of the root canal. J Endod. 2008;34(12):1524-1527. doi:10.1016/j. joen.2008.08.029.

61. Li D, Jiang S, Yin X, Chang JW, Ke J, Zhang C. Efficacy of needle, ultrasonic, and endoactivator irrigation and photon-induced photoacoustic streaming in removing calcium hydroxide from the main canal and isthmus: An in vitro micro-computed tomography and scanning electron microscopy study. Photomed Laser Surg. 2015;33(6):330337. doi:10.1089/pho.2015.3903.

62. Gokturk H, Ozkocak I, Buyukgebiz F, Demir O. Effectiveness of various irrigation protocols for the removal of calcium hydroxide from artificial standardized grooves. J Appl Oral Sci. 2017;25(3):290-298. doi: 10.1590/16787757-2016-0414.

63. Arslan H, Akcay M, Capar ID, Saygili G, Gok T, Ertas H. An in vitro comparison of irrigation using photon-initiated photoacoustic streaming, ultrasonic, sonic and needle techniques in removing calcium hydroxide. Int Endod J. 2015;48(3):246-251. doi:10.1111/iej.12306.

64. Lloyd A, Navarrete G, Marchesan MA, Clement D. Removal of calcium hydroxide from Weine Type II systems using photon-induced photoacoustic streaming, passive ultrasonic, and needle irrigation: a microcomputed tomography study. J Appl Oral Sci. 2016;24(6):543-548. doi:10.1590/1678-775720160234.

65. Akcay M, Arslan H, Mese M, Sahin NN. The effect of photon-initiated photoacoustic streaming, ultrasonically and sonically irrigation techniques on the push-out bond strength of a resin sealer to the root dentin. Clin Oral Investig. 2015;19(5):1055-1061. doi:10.1007/s00784-0141332-0.

66. Akyuz Ekim SN, Erdemir A. Effect of different irrigant activation protocols on push-out bond strength. Lasers Med Sci. 2015;30(8):2143-2149. doi:10.1007/s10103-0151772-z.

67. Arslan H, Akcay M, Saygili G, Keskı A, MeŞe İT, Gok A, et al, Bond strength of self-adhesive resin cement to root dentin. Comparison of photon-initiated photoacoustic streaming technique with needle and ultrasonic irrigation. Acta Odontol Scand. 2015;73(5):348-52. doi:10.3109/00016 357.2014.967717.

68. Akcay M, Arslan H, Mese M, Durmus N, Capar ID. Effect of photon-initiated photoacoustic streaming, passive ultrasonic, and sonic irrigation techniques on dentinal tubule penetration of irrigation solution: a confocal microscopic study. Clin Oral Investig. 2017;21(7):22052212. doi:10.1007/s00784-016-2013-y.

69. Akcay M, Arslan H, Durmus N, Mese M, Capar ID. Dentinal tubule penetration of AH Plus, iRoot SP, MTA fillapex, and guttaflow bioseal root canal sealers after different final irrigation procedures: A confocal microscopic study. Lasers Surg Med. 2016;48(1):70-76. doi:10.1002/lsm.22446.

70. Miletić I, Chieffi N, Rengo C, Ferrari M, Nathanson D, Baraba A. Effect of photon induced photoacoustic streaming (PIPS) on bond strength to dentine of two root canal filling materials. Lasers Surg Med. 2016;48(10):951954. doi:10.1002/lsm.22536.

71. Vangala A, Hegde V, Sathe S, Dixit M, Jain P. Effect of irrigating solutions used for postspace treatment on the push-out bond strength of glass fiber posts. J Conserv Dent. 2016;19(1):82-6. doi:10.4103/0972-0707.173206.

72. Yost RA, Bergeron BE, Kirkpatrick TC, Roberts MD, Roberts HW, Himel VT, et al, Evaluation of 4 different irrigating systems for apical extrusion of sodium hypochlorite. JEndod. 2015;41(9):1530-1534. doi:10.1016/j. joen.2015.05.007.

73. Azim AA, Aksel H, Margaret Jefferson M, Huang GT. Comparison of sodium hypochlorite extrusion by five irrigation systems using an artificial root socket model and a quantitative chemical method. Clin Oral Investig. 2018;22(2):1055-1061. doi:10.1007/s00784-017-2187-y.

74. Arslan D, Kustarci A. Efficacy of photon-initiated photoacoustic streaming on apically extruded debris with different preparation systems in curved canals. Int Endod J. 2018;51(Suppl 1):e65-e72. doi:10.1111/iej.12816.

75. George R, Walsh LJ. Apical extrusion of root canal irrigants when using Er:YAG and Er,Cr:YSGG lasers with optical fibers: An in vitro dye study. J Endod. 2008;34(6):706-708. doi:10.1016/j.joen.2008.03.003.

76. Kishen A, Haapasalo M. Biofilm models and methods of biofilm assessment. Endod Topics. 2012;22(1):58-78. doi:10.1111/j.1601-1546.2012.00285.x.

77. Marion JJC, Manhães FC, Bajo H, Duque TM. Efficiency of different concentrations of sodium hypochlorite during endodontic treatment. Dent Press Endod. 2012;2(4):32-37.

78. Wang Z, Shen Y, Haapasalo M. Effectiveness of endodontic disinfecting solutions against young and old Enterococcus faecalis biofilms in dentin canals. J Endod. 2012;38(10):1376-1379. doi:10.1016/j.joen.2012.06.035.

79. Koch JD, Jaramillo DE, DiVito E, Peters OA. Irrigant flow during photon-induced photoacoustic streaming (PIPS) using Particle Image Velocimetry (PIV). Clin Oral Investig. 2016;20(2):381-386. doi:10.1007/s00784-015-1562-9.

80. De Meyer S, Meire MA, Coenye T, De Moor RJ. Effect of laser-activated irrigation on biofilms in artificial root canals. Int Endod J. 2017;50(5):472-479. doi:10.1111/ iej.12643.

81. Arslan H, Akcay M, Ertas H, Capar ID, Saygili G, Meşe M. Effect of PIPS technique at different power settings on irrigating solution extrusion. Lasers Med Sci. 2015;30(6):1641-1645. doi:10.1007/s10103-014-1633-1.

82. Huiz Peeters H, Suardita K, Mooduto L, Gutknecht N. Extrusion of irrigant in open apex teeth with periapical lesions following laser-activated irrigation and passive ultrasonic irrigation. Iran Endod J. 2018;13(2):169-175. 